\title{
CRITICIZE THE USE OF ANALOGY PROHIBITION IN CRIMINAL LAW
}

\author{
Ali Masyhar Mursyid* \\ Department of Criminal Law, Faculty of Law Universitas Negeri Semarang, Semarang \\ Building K Kampus Sekaran, Gunungpati, Semarang 50229
}

\begin{abstract}
The analogy becomes an absolute thing that is not permitted under the Indonesia criminal law. However, in the moving and changing society, written criminal laws are not always able to accommodate all the crime that happened. The prohibition of analogy it is not in line with Islamic law, "qiyas", which no other is the analogy. Analogy should be accepted as part of a form of interpretation that has been known in the criminal law. Ban the use of analogy also confirmed in the draft Criminal Code. However, reading the ban of analogy must be done carefully.
\end{abstract}

Keywords: analogy, criminal law

\section{Intisari}

Analogi menjadi satu hal mutlak yang tidak diperkenankan dalam hukum pidana. Namun demikian di tengah perkembangan masyarakat yang bergerak dan senantiasa berubah, perundang-undangan pidana tertulis tidak selamanya mampu menampung seluruh tindak pidana yang terjadi. Doktrin hukum pidana yang melarang analogi ini justru tidak sejalan dengan konsep hukum Islam yang mengenal qiyas, yang tiada lain adalah analogi. Seyogyanya analogi bisa diterima sebagai bagian dari bentuk penafsiran yang selama ini telah dikenal dalam hukum pidana. Larangan penggunaan analogi juga ditegaskan (kembali) dalam Rancangan KUHP. Namun demikian perlu kehati-hatian dalam membaca larangan analogi dalam Rancangan KUHP ini.

Kata Kunci: analogi, hukum pidana.

\section{Pokok Muatan}

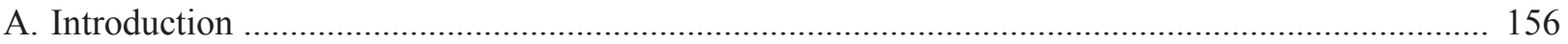

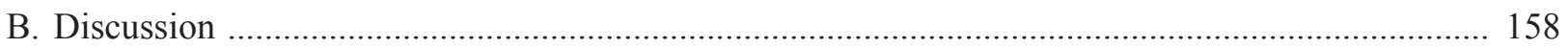

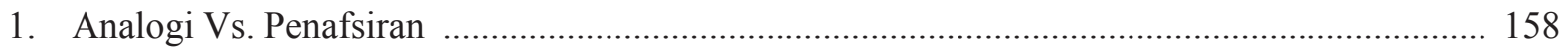

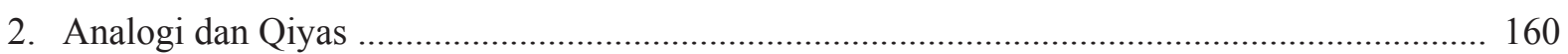

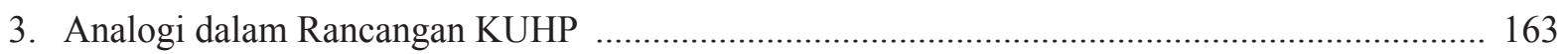

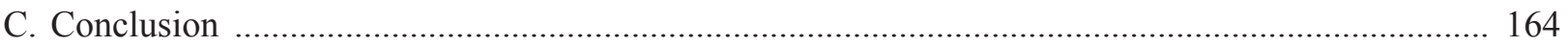




\section{A. Introduction}

Early foundation in the study of criminal law in Indonesia is the principle of legality, Nullum delictum nulla poena sine praevia lege poenali. No offense, no criminal without any prior existence of criminal laws that declare in advance. In literature and doctrine, this principle can be interpreted that to ensnare a person with criminal law required there are 3 signs that must be met, namely: (1) there must be a written rule; (2) written rules that must exist before the act (crime) was performed; and (3) are not allowed to use an analogy.

Both of the first signs that the law must be written and must be present before the criminal action, all this has been a lot of discussion by experts. Perceived lack of understanding is a balanced portion of the analogy. The analogy was taboo, especially for the scholars. The analogy is often a forbidden topic to be explored in the criminal law. Criminal law only recognize words and sentences firm and non-ambiguous.

Indonesian dictionary ${ }^{1}$ defines an "analogy" as follows: (1) the equation or correspondence between two objects or different things; figurative (2) equivalence between language forms the basis of the occurrence of other forms; (3) something similar in shape, arrangement, or function, but different origin so that there is no kinship; (4) The most characteristic similarity between two objects or things that can be used for a basis of comparison. Being "analogy" is defined as making something new based on existing examples; they invented a new word forms are modeled on existing forms.

IHDI Ranuhandoko interpret analogy is a common principle contained in two or more problems. The analogy comes from the Greek analogos which contains similarity that can be filed analogy. ${ }^{2}$ While Black's Law Dictionary interprets as identity or similarity of proportion, where there is no precedent in point. In cases on the same subject, lawyers have recourse to cases on a different subjectmatter, but governed by the same general principle. This is reasoning by analogy. The similitude of relations which exist between things compared. ${ }^{3}$

This paper aims to interpret the position of analogy in criminal law. During this analogy into illicit goods in criminal embedding method against perpetrators that are not defined in the legislation. Although the substance of his actions is clearly equal to the law.

Indeed, there is no perfect formulation. Perfection belongs only to God. People should be aware of its inability to describe reality with words. Even the true man does not understand the power of the actual condition of the substance that is being arranged. He was only able to get closer to the real truth. In the case of rulemaking (legislation), humans are also not able to reach any peruabahanwhat changes later in life. When making laws, legislators only make a "momentopname" only in terms of a social interaction. Therefore, conditions such as those experienced members are able to be photographed, although not entirely perfect. Whereas social reality constantly moving, changing. Community life nothing is static, it constantly moving, changing. Moreovr, it is certainly behind the legislation is often the least developed in the development of society. Act as a positive legal system, is static. Therefore, the law as a static element (statisch element), can not follow the development of society, it often happens empty spaces in the legislation (leemten in de Wetten). ${ }^{4}$ The emergence of this empty space to give the task to judge and legal bearers officials to close it. Thus, the judge should adjust the static laws with changing social circumstances after the law was made. This is where the need for interpretation and analogy.

Analogy in the history of the Indonesian legal system, has been there since the existence of Undang- Undang Darurat No. 1/Drt/1951

\footnotetext{
Badan Pengembangan dan Pembinaan Bahasa, Kementerian Pendidikan dan Kebudayaan RI, Kamus Besar Bahasa Indonesia, http://kbbi. web.id/analogi, diakses 19 Sepetember 2013 pukul 09.20.

Ranuhandoko, IPM, 2006, Terminologi Hukum, Sinar Grafika, Jakarta, hlm. 54.

Bryan A. Garner, 1990, Black's Law Dictionary, West Publishing Co, St. Paul, Minn. hlm. 84
} 
tentang Tindakan-Tindakan Sementara untuk Menyelenggarakan Kesatuan Susunan Kekuasaan dan Acara Pengadilan-Pengadilan Sipil. Pasal 5 ayat (3) sub b Undang-Undang Darurat No. 1/Drt/1951 that "Hukum materiil sipil dan untuk sementara waktu pun hukum materiil pidana sipil yang sampai kini berlaku untuk kaula-kaula daerah Swapraja dan orang-orang yang dahulu diadili oleh Pengadilan Adat, ada tetap berlaku untuk kaula-kaula dan orang itu, dengan pengertian: bahwa suatu perbuatan yang menurut hukum yang hidup harus dianggap perbuatan pidana, akan tetapi tiada bandingnya dalam Kitab Hukum Pidana Sipil, maka dianggap diancam dengan hukuman yang tidak lebih dari tiga bulan penjara dan/atau denda lima ratus rupiah, yaitu sebagai hukuman pengganti bilamana hukuman adat yang dijatuhkan tidak diikuti oleh pihak terhukum dan penggantian yang dimaksud dianggap sepadan oleh hakim dengan besar kesalahan yang terhukum, bahwa, bilamana hukuman adat yang dijatuhkan itu menurut fikiran hakim melampaui padanya dengan hukuman kurungan atau denda yang dimaksud di atas, maka atas kesalahan terdakwa dapat dikenakan hukumannya pengganti setinggi 10 tahun penjara, dengan pengertian bahwa hukuman adat yang menurut faham hakim tidak selaras lagi dengan zaman senantiasa mesti diganti seperti tersebut di atas, dan bahwa suatu perbuatan yang menurut hukum yang hidup harus dianggap perbuatan pidana dan yang ada bandingnya dalam Kitab Hukum Pidana Sipil, maka dianggap diancam dengan hukuman yang sama dengan hukuman bandingnya yang paling mirip kepada perbuatan pidana itu".

By looking at the provision of the Article 5 section (3) b Undang-Undang Darurat No. 1/ Drt/1951, there're some legal principles as the following:

1. The traditional criminal law is still alive, still recognized as a source of law/ used as a basis for deciding the case / criminal offense for judges;
2. customary sanctions can be used as the main criminal judge in check and prosecute acts according to the law of life is considered as a crime that has no counterpart in the Criminal Code;

3. The offenses custom incomparable/ counterpart in the Criminal Code if it is not considered severe or mild customary criminal offense criminal threats:

a. jika sifatnya tidak berat atau yang dianggap tindak pidana adat yang ringan ancaman pidananya:

1) imposed sanctions / penalties customary; or if not followed;

2) subject to a maximum imprisonment of 3 months and / or a fine of five hundred dollars;

b. If it is severe or serious criminal offenses customary criminal threats:

1) If the sanctions / penalties in line with customary (progress) era, subject to sanctions / penalties customary;

2) If the sanctions / penalties are not in harmony with the indigenous (progress) era, subject to a maximum imprisonment of 10 years;

c. Criminal acts no counterpart in the Criminal Code, the same criminal threats with criminal threats that exist in the Criminal Code.

Thus the formal legal system conceived by the Indonesian nation itself justify the imposition of 
a similar offense or the like. This is considered as an analogy. Citing the views Manheim, Andi Hamzah stated there are two types of analogy is gesetzes analogie (analogy of rule) and recht analogie (analogy of law). ${ }^{5}$ Gesetzes analogie is an act can be imprisoned, although not set in legislation, if the people want, using / applying the most similar article by analogy. While recht analogy is analogous to act substantively an act of harm, although there are similarities with the clauses in legislation. The formulation of Article 5 paragraph (3) sub b Emergency Law Number 1/ Drt / 1951 are included in the category of gesetzes analogie.

If the law is interpreted as rules/guidelines man in stride, then in it there is no difference between the strata law is written with unwritten. Written law does show his form concrete, and (perhaps) objective. But the unwritten law is no less concrete because it manifests in the behavior of people's daily life. Written law because of "sure" it is often rigid and less able to follow the development of the society. Hence the phrase "het recht hinkt achter de feiten aan" (law always lags of society), to obtain legal justification in this written law. For help and anticipate in order to avoid dropping and legal vacuum with the development community, it is better explored this analogy problems.

\section{B. Discussion}

\section{Analogy vs. Interpretation}

While these experts are still arguing about the permissibility of analogy in understanding the meaning of the criminal law. Some suggested a very tight and stiff that it is not allowed to use the analogy, while others allow this group of lawyers who do not allow analogy is Simons, Zevenbergen, van Hamel, and Langemeijer. Other legal experts like Taverne, Pompe, Jonkers, Roling, and Scholten moderate category and allow the use of analogy.
To a first view states that are allowed in the interpretation of the meaning of criminal law only, including various variants such as an authentic interpretation, systematically, a contrario, grammatical, historical, etc. extensively. For this group the analogy is in fact not include the category of interpretation, so it should not be used to interpret the rules. Adherents of the second opinion holds that analogy can also be categorized as a form of interpretation, namely the interpretation of analogy (argumentum per analogiam).

Both groups who reject the analogy and the receiver, each of which has a rational reason. The analogy is accepted because it is based rational thought that the development of society so rapidly that the criminal law should be developed in accordance with the development of society. Though aware that there is no one formula that is able to cover the motion law public movement. In more realistic analogy is needed to overcome the legal vacuum as will discuss above.

The analogy is rejected because it is based reasoning maintain legal certainty. Legal uncertainty open space, thus he has violated himself, being unable to provide legal guarantees to the adressat. To prevent legal uncertainty in the community, then it prohibits the use of analogy. Furthermore, they argued that the application of the analogy can harm the joints of law and justice because they cause legal uncertainty in society. Preventing legal uncertainty in the community, then it prohibits the use of analogy. Furthermore, they argued that the application of the analogy can harm the joints of law and justice because they cause legal uncertainty in society. ${ }^{6}$ This reasoning is based on the feelings of trauma during the Nazi rule of law according to their intended use. With this background, understand if the use of the analogy is rejected by majority scholars in Europe and Netherland.

Andi Hamzah,2010, Asas-Asas Hukum Pidana, Rineka Cipta, Jakarta, hlm. 47

One of the aims of the prohibitation of appliction by analogy is that of protecting the individual from arbitrary state conduct, implying that it should be up to the legislature to determine certain conduct as punishable. Jescheck and Weigend sebagaimana dikutip Machteld Boot, 2002, Nullum Crimen Sine Lege and The Subject Matter Jurisdiction of The International Criminal Court: Genocide, Crimes Against Humanity, War Crimes, Intersentia, Oxford, New York, hlm. 101. 
Scholten looked at the similarities between extensive interpretations by analogy. According to Scholten, both in terms of interpretation of analogy and extensive interpretation is essentially the same, namely to try to find the norms of higher (more general or abstract) of the existing norms, and from this it then reduced to the new rules (which actually expands existing rules). Even difference between those two is only gradual difference. ${ }^{7}$

Examples of extensive interpretation is phenomenal Dutch HR decision in 1921 which define the meaning of "goed" (objects, goods) in Article 362 of the Criminal Code (theft) also include electrical power. So the electric power can also be equated with 'goed', therefore he can be treated offense under Article 362 of the Criminal Code. According to the author of this view is a concrete example that the analogy is allowed in criminal law. For those who do not agree with the analogy, the view that the HR decision not indicate the use of analogy, but uses extensive interpretation. The word 'goed' at the time WvS formed only meaningful as tangible goods, while at the present time also includes intangible goods.

Another example can be considered as the use of analogy in criminal law (though eventually canceled assemblies' cassation) is a case of "fraud" in Tapanuli. Judge Bismar Siregar, who was hearing the case decided there has been a violation of Article 378 of the Criminal Code on the deposit "bonda" by a woman to a man who intercourse her by promising to marry the woman. The case began when Mertua Raja Sidabutar (a married men who worked as a contractor) dating a underage girl named Catherine Br. Siahaan. During courtship, Mertua promised (it even has a letter from the relevant evidence) to marry Catherine. Interested in this promise, Katarina willing to give up her virginity to the in-laws. However, on his way in-law breaking this promise, so the Katarina police. This case of criminal proceedings, until finally judged in
PN field.

Medan District Court Number 571/KS/1980/ PN.Mdn, dated 5 March 1980 stating that the defendant-law legally and convincingly proven guilty of committing obscene acts with a woman who is not his wife, and the defendant was sentenced to three months in prison, but will not run with a 6-month trial period. Apropos to the court verdict, prosecutors did appeal to the high court.

In this case, the appeal was handled by Judge Bismar Siregar. Bismar Siregar argued that the right of civil law in terms of the engagement of such a law is null and void because it was based on a pedestal which is not lawful rights and contrary to the law, and thus (by perspective of civil law) although there is a breach of contract, the woman cannot be sued before the law. However, it's different according to the perspective of criminal law. Judge Bismar stated that the men should be responsible because of breaching the agreement between the man and the woman. Because intercourse/virginity Katarina delivery occurred because the presence of persuasion and guile of Mertua Siahaan. Bismar used analogy that there has been fraud by-laws on Katarina Siahaan. While the items become the object of fraud is "genitals" analogy woman as goods. Bismar base "stuff" in Tapanuli is "bonda" which can also be interpreted as "genitals". Katarina (victim) surrender her virginity to the inlaws (the perpetrator) because of the presence of persuasion about to be married, was tantamount to handing bonda (goods) as a ruse. On this basis the Judge decided there had been a violation of Article 378 KUHP by the actor (Mertua) and criminal sentencing. But the Judge's decision was canceled by the Supreme Court because they do analogies, which is actually prohibited in criminal law ${ }^{8}$.

From the two examples are very similar to the above, the views of experts were also split. For experts who since the beginning rejected the analogy assume that in the first case (HR Netherlands in

Moeljatno, 1987, Azas-Azas Hukum Pidana, Bina Aksara, Bandung, hlm. 26.

Putusan Pengadilan Tinggi Medan, Sumatera Utara, No. 144/Pid/1983/PT Mdn, perihal Penipuan dalam Berpacaran, 8 Agustus 1983. 
1921) the judge did not use the analogy, but still within the interpretation scope, is an extensive interpretation. In extensive interpretation, still stick to the rules. There are words which are given meaning by the meaning of life in today's society, not according to its meaning when legislation was formed. This is in contrast to the second case, namely Medan High Court Decision Number 144/ Pid./1983/PT.Mdn. Thus, the judge was out of line interpretation. The judge had used the analogy that ought to be rejected.

Therefore, it's exactly distinguishes between analogy and extensive interpretation? For those who reject the analogy of trying to give an explanation, there is a significant difference between analogy and interpretation. Analogy obviously be rejected because the act substantially problem cannot be included in the existing rules. But in the view of the judge considered to be a criminal anyway, because it includes the core rules that are similar to that action. Because it includes the core of an existing rule that action can then be subject to the existing rules by using the analogy. The use of analogy obviously jeopardize justice and tends to injure the law itself because it is used as the basis for certain acts criminalized not, no longer existing rules, but the ratio of purpose, the core of the existing rules. Therefore deemed no longer hold on to the existing rules, but at the core, the ratio of him, then clearly diametrically opposed to the principle of legality, because this principle requires the existence of a rule as a basis.

This is very different from the extensive interpretation. Extensive interpretation still stick to sound rules, all the words still be followed, there are only words that are no longer interpreted as the time he made the law, but at the time of its use, therefore it is called interpretation. ${ }^{9}$

Sudikno Mertokusumo confirmed the basic point of the extensive interpretation that the distinguishing feature with the analogy that extensive interpretation is not the case any vacancy in the law, the law is complete, just not clear, so it needs to be explained or interpreted. The judge in this case did not complete the legislation with something new, something the judge did not apply outside the laws that have been there, but he was still holding on to existing laws and not creating new regulations. ${ }^{10}$

For adherents of the receipt of analogy assumes no principal difference between the first and second cases (HR decision Netherlands in 1921 and the High Court of Medan No. 144/Pid/1983/ PT.Mdn) this. Judge equally provide equality between noun (goed) of the Criminal Code with reality incident cases. But why for the first case (HR Netherlands in 1921) can be accepted, while the second case (Medan High Court Decision No. 144/ Pid/1983/PT.Mdn) rejected. This is where it happens the double standard used by the repellent analogy. The author himself believes there is no significant difference between extensive interpretation and analogy ${ }^{11}$. Keduanya merupakan penafsiran hukum yang patut diberi ruang demi tersajinya keadilan di tengah-tengah masyarakat. Apapun metode yang digunakan oleh hakim, seyogyanya tidak perlu dilarang, sepanjang digunakan sebagai ijtihad hadirnya nilai keadilan bagi justiciabellen .

\section{Analogy and Qiyas}

Terminology of Qiyas is derived from the Arabic word قياس that means measure, equating. Qiyas according to the language defined by measuring a thing with something like it. According to sholars of ushul fiqh, terminology of qiyas is likening a case that no legal texts with an existing case law texts, the existing nash law, because the second equation in illat of law. ${ }^{12}$ In addition, many other definitions of qiyas which is defined as the 
legal explain something that has no nash in the Qur>an and hadith by comparing it with something that is determined based on nash. ${ }^{13}$

Based on some definitions of qiyas, it can be concluded understanding law qiyas is set for an event or events that no nashnya basis in the Qur'an and Sunnah by way of legal equate with an event or events that other predetermined law based on the texts because of the same illat between two events or events. For instance, qiyas is equate something that has no legal texts with something that has no legal texts because illat same ruling.

Scholarly accept and use qiyas as a source of Islamic law in the fourth, that is, after al-Qur'an, Sunnah, and the consensus'. Many verses of the Koran that can be used as the basis of orders do qiyas, one of which is:

"Hai orang-orang yang beriman, taatilah Allah dan taatilah Rasul (nya), dan ulil amri di antara kamu. Kemudian jika kamu berlainan pendapat tentang sesuatu, Maka kembalikanlah ia kepada Alloh (Al Quran) dan Rasul (sunnahnya), jika kamu benarbenar beriman kepada Allah dan hari kemudian. yang demikian itu lebih utama (bagimu) dan lebih baik akibatnya”. (QS. An-Nisa' : 59)

In the above verse gives direction to the ummah believer (believer) that first adhered to the Law of Allah SWT (law in the Qur'an), then obey the Apostle (law in the Sunnah) and obey the leader (results ijma 'ulama). In case, there is a difference of opinion on something that is not legal in the Book of Allah, the Sunnah Rosululloh and ulil amr, then we were told to return to Allah and His prephet. This restores meaning by scholarly 'is defined by the command qiyas.

In another verse Allah Almighty says:
"Dia-lah yang mengeluarkan orang-orang kafir di antara ahli Kitab dari kampungkampung mereka pada saat pengusiran yang pertama. kamu tidak menyangka, bahwa mereka akan keluar dan merekapun yakin, bahwa benteng-benteng mereka dapat mempertahankan mereka dari (siksa) Alloh; Maka Alloh mendatangkan kepada mereka (hukuman) dari arah yang tidak mereka sangka-sangka, dan Alloh melemparkan ketakutan dalam hati mereka; mereka memusnahkan rumah-rumah mereka dengan tangan mereka sendiri dan tangan orangorang mukmin. Maka ambillah (kejadian itu) untuk menjadi pelajaran, hai orang-orang yang mempunyai pandangan.(QS. al-Hasyr :2)

In the last sentence the word of Allah SWT asserts: "(Then take it (the incident) to be a lesson, O people who have the view), that is: Allah ordered "do qiyas with them, Verily, you are a human as they, if you do as what they do, it will come to you (punishment) as he had come to them". ${ }^{14}$

In addition to the arguments of the Qur'an which implies command qiyas, qiyas also been done Prophet Muhammad when facing the problems that prompted the ummah. Among the issues judged by the way qiyas is ibroh of Prophet Muhammad against a girl who asks questions about the pilgrimage to his parents who are already obliged to perform the pilgrimage, but his physical condition elderly. Prophet made a qiyas regarding to "pay the debt to the parents who have debts". Those cases are equally mandatory and must be implemented.

The next case is when Umar Bin Khattab asks associated with a kiss on while implementing fast, without removing semen. Prophet Muhammad used qiyas by rinsing for people who are fasting. That is equally not break his fast.

\footnotetext{
11 Lihat juga pandangan Utrecht yang menegaskan pada hakikatnya tidak ada perbedaan antara interpretasi ekstensif dan analogi. Dalam kedua hal itu, hakim membuat konstruksi, yaitu membuat (mencari) suatu pengertian hukum yang tinggi. Hakim membuat suatu kaidah yang lebih tinggi dan yang dapat dijadikan dasar beberapa ketentuan yang mengandung kesamaan...Utrecht, Op.Cit, hlm. 212.

12 Abdul Wahab Khallaf, 1994, Ilmu Ushul Fiqh (alih bahasa: M. Zuhri dan Ahmad Qorib), Dina Utama, Semarang, hlm. 66. Lihat juga Mukhtar Yahya dan Fatchurrahman, 1986, Dasar-Dasar Pembinaan Hukum Fiqih Islami, PT. Al-Ma'arif, Bandung, hlm. 66

13 Syaifuddin Zuhri, Makalah Usul Fiqih “Qiyas”, http://muhammadzuhri.wordpress.com/2011/08/21/makalah-ushul-fiqih-qiyas/, diakses pada tanggal 19 September 2013 jam 09.15.

14 Abdul Wahab Khallaf, Op.Cit, hlm. 71
} 
Implementation of qiyas is justified to the extent that the pillars are fulfilled, namely al-ashl, al-Furu', Law and al-illat ashl.

a. al-Ashl.

Ashl, is an event that has existed / legal defined either in the Qur'an or Sunnah that is used as the basis for making qiyas. He also referred to the Maqis' alaih (where implementing qiyas) are references to him are to be equated with the law another container.

b. Furu'

Fara'/Furu', is denifed as branch, which is an event that has not been determined because no legal texts that can be used as the basis. Fara' also called Maqis (measured) or musyabbah (who likened) or mahmul (the comparison).

c. Law of Ashl

Law of ashl, is law of hukum syara' which is decided by a nash, therefore intended to justify a law of its branches. The terms of the law of al-ashl, namely: ${ }^{15}$

1) The law of ashl should be legal personality 'Amali (the work of mukallaf) set by the texts;

2) The law ashl should be classified as a law that can be achieved by reasonable illatnya;

3) Legal ashlnya not devoted to anything.

d. Illat

Illat is a cause that makes the law of something. With this new equation can use qiyas second problem (furu ') to the first issue (ashl) due to a cause that can be compromised between the origin of the furu'.

Illat literally means something that could change the situation, for example, a disease called illat because it changed the condition of a person affected by the disease. According to the terms, as stated Abdul Wahhab Khallaf, illat is a trait in ashl having their legal basics. The way to find out illat is through the arguments of the Qur'an or the Sunnah, either expressly or indecisive, knowing illat through ijma', and through the ijtihad.

The way to find out illat is through the arguments of the Qur'an or the Sunnah, either expressly or indecisive, knowing illat through ijma', and through the ijtihad.

The terms illat are:

1) Illat must be clear and visible nature;

2) Illat must be strong;

3) There must be a correlation (corresponding relationship) between the law of the nature of being illat;

4) Properties become illat who later gave birth to qiyas must be far-reaching, not limited to a particular law; and

5) It is not declared void by a proposition.

Apropos to the the admissibility of qiyas in Islamic law, the analogy can also be accepted throughout fulfil four conditions, namely:

a. There are clear rules on the basis of certain acts prohibited (no debate about banning on which to base);

b. Acts that analogy is absolutely disgraceful act and yet there is a rule (positive law) which forbade; 
c. Laws/rules that analogy (which made backrest analogy) is a rule that clearly in question, does not change the minimum for a long period of time.

d. There is a similarity value or at least the principles concerning the reprehensible between acts that have no rule of law with the analogous.

e. If not done analogy, the despicable act be not be liable to criminal prosecution.

\section{The Use of Analogy in Draft of Criminal Code (KUHP}

After discussing the pros and cons of analogy in criminal law, it was his turn exposes ius constituendum analogy in Indonesia. However, there is no harm should review some of the analogies in ius constitutum (Criminal Code). Criminal Code (WvS) does not explicitly formulate this analogy ban. Prohibition concluded as consequence of logical analogy of nullum crimen, nulla poena sine lege stricta which became one of the pillar of the principle of legality that was formulated in Article 1 paragraph (1) of KUHP. The principle asserts that there is not a criminal, there is no crime in the absence of strict laws. Thus the law must be strict formulate what conduct is prohibited. The formulation in Article 1 of KUHP is Simons found itself Penal Code prohibits any application of the law by analogy in criminal law, therefore, the application of such a law can make an act that were not explicitly stated as a criminal offense became a crime. Even Van Bemmelen view that Article 1 paragraph (1) of KUHP, it is also a guarantee for preventing the actions that can not be accounted for by the police. Each investigation and prosecution that began with an allegation, namely that a person has committed a crime. Since the beginning, the police and prosecutors were forced by Article 1 (1) of the Criminal Code to investigate whether a particular event it really is an event that has been organized in a criminal provision or not. Thus they can be easily said that what had happened was similar to an act which by law has been declared as a criminal offense, and therefore entitled to do penahaanan and confiscation of of certain goods.

Van Hammel found on the legality of the rule prohibiting the use of interpretation by analogy, therefore, such an interpretation is not only able to expand the number of offenses that have been prescribed by law, but also can lead to more diperberatnya or more diperingannya penalties may be imposed for whichever is done not by law.

Unlike the Criminal Code (WvS) that are not explicitly formulate ban analogy, design/concept of the Penal Code explicitly formulate restrictions on the use of analogy. The prohibition confirmed by the Article 1 paragraph (2) draft of KUHP in 2013 that "in determining the existence of a criminal offense, it is prohibited to use analogy".

The formulation of the draft Criminal Code prohibition analogy should be read in one breath with the principle of legality as defined in paragraph (1) her (Article 1 Draft of KUHP) is formulated as the following:

Nobody can be imprisoned or subjected to the action, except for acts committed establish as criminal offenses under the legislation in force at the time the act was committed.

By the affirmation in Article 1 (2) design / concept of the Criminal Code (2013) The analogy becomes clear that illicit goods to be used in the Indonesian criminal law enforcement. Assertions are so tight in fact it is a step back from the political Indonesian criminal law (penal policy). Criminal rules (written) assumed to be covered in full in the formulation of the Criminal Code. Yet the reality was actually not the case. There will always be, the shape and pattern of new the criminal action that are likely to expand, according to the development of human civilization. So what should we think, if 
only occurs act formally not netted in the rule of law (written), whereas in fact the act has actually cause harm, while no written rules governing the the criminal action that are similar to the that are not regulated? Is it better to be squelched, give impunity to the perpetrators of these the criminal action? Whereas in our positive law also outlines that the judge should not reject the case with no legal basic. ${ }^{16}$

Against such conditions Utrecht view that rejects the analogy of a priori means tacitly embracing a very narrow positivistic stream that can not be adapted to today. ${ }^{17}$ Pompe argued analogy can be justified if the laws that are void/leemte, which is caused by the legislators forgot to set a specific or are not aware of the possibility of the occurrence of some event in the future and formulate criminal provisions that are so narrow that there or events can not be incorporated into the criminal provisions in question. ${ }^{18}$

Alternative way seems to be taken by Wirjono Prodjodikoro who advised that analogy should not be absolutely prohibited or allowed in criminal law, but should be on every question in concreto seen on the intent and purpose of the legislators concerned about particular issues. ${ }^{19}$ Thus, to see the analogy Wirjono need special handling based on case by case methode.

\section{Conclusion}

A rule of criminal law is essentially a set of addressant law and at the same time limiting law enforcement so as not to act arbitrarily. On the one hand, the prohibition of analogy is intended as personal protection on the potential arbitrariness of law enforcement officers, but on the other hand also can threaten the sense of justice if there is impunity for the the criminal action in the community.

Prohibition analogy with its use without any gap will obviously lead to the rigidity of law, and are likely tied to legal positivism. In fact, as a nation that is still under construction law, law of elasticity should be given space in order to achieve justice. Justice becomes the ultimate goal of our lawless, toward a prosperous society. Whatever experiments should still be given appreciation. Because the law is true for human well-being, and not vice versa.

However, one thing to remember is to continue to build a culture arbitrate itself, both the legal culture of society and law enforcement agencies themselves. Because he made a penal reform (penal reform) without change in culture reform (primarily for law enforcement), the same means give the sword to anyone with the freedom to use it.

\section{BIBLIOGRAPHY}

\section{A. Buku}

Garner, Bryan A., 1990, Black's Law Dictionary, West Publishing Co, St. Paul, Minn.

Boot, Machteld, 2002, Nullum Crimen Sine Lege and The Subject Matter Jurisdiction of The International Criminal Court: Genocide, Crimes Against Humanity, War Crimes, Intersentia, Oxford, New York.

Hamzah, Andi, 2010, Asas-Asas Hukum Pidana,
Rineka Cipta, Jakarta.

Khallaf, Abdul Wahab, 1994, Ilmu Ushul Fiqh (alih bahasa: M. Zuhri dan Ahmad Qorib), Dina Utama, Semarang.

Mertokusumo, Sudikno, 2014 (cetakan ke-5), Penemuan Hukum: Sebuah Pengantar, Universitas Atma Jaya, Yogyakarta.

Moeljatno, 1987, Azas-Azas Hukum Pidana, Bina Aksara, Bandung.

\footnotetext{
16 Pasal 10 UU No. 48 Tahun 2009 tentang Kekuasaan Kehakiman (Lembaran Negara Republik Indonesia Tahun 2009 Nomor 157, Tambahan Lembaran Negara Republik Indonesia Nomor 5076).

E. Utrecht, 1994, Op.Cit, hlm. 218

Ibid, hlm. 215

Wirjono Prodjodikoro, 2009, Asas-Asas Hukum Pidana di Indonesia, Edisi ke-3. Refika Aditama, Bandung, hlm. 100.
} 
Prodjodikoro, Wirjono, 2009, Asas-Asas Hukum Pidana di Indonesia, Edisi ke-3. Refika Aditama, Bandung.

Ranuhandoko, IPM, 2006, Terminologi Hukum, Sinar Grafika, Jakarta.

Utrecht, 1994, Rangkaian Sari Kuliah Hukum Pidana I, Pustaka Tinta Mas, Surabaya.

Yahya, Mukhtar, dan Fatchurrahman, Dasar-Dasar Pembinaan Hukum Fiqih Islami, PT. AlMa'arif, Bandung.

\section{B. Internet}

Badan Pengembangan dan Pembinaan Bahasa, Kementerian Pendidikan dan Kebudayaan, Kamus Besar Bahasa Indonesia, http://kbbi. web.id/analogi, accessed on 19 Sepetember 2013.
Zuhri, Syaifuddin, Makalah Ushul Fiqih "Qiyas", http://muhammadzuhri.wordpress. com/2011/08/21/makalah-ushul-fiqih-qiyas/, accessed on 19 September 2013.

\section{Putusan Pengadilan}

Putusan Pengadilan Tinggi Medan, Sumatera Utara, No. 144/Pid/1983/PT Mdn, perihal Penipuan dalam Berpacaran, tanggal 8 Agustus 1983.

\section{Peraturan Perundang-undangan}

Undang-Undang Nomor 48 Tahun 2009 tentang Kekuasaan Kehakiman (Lembaran Negara Republik Indonesia Tahun 2009 Nomor 157, Tambahan Lembaran Negara Republik Indonesia Nomor 5076). 